\title{
A Qualitative Inquiry in to the Impact of an Arts-Based, Self-Portrait Assignment on Third Year Child and Youth Care Students
}

Gerard Bellefeuille: Professor, Department of Child and Youth Care, MacEwan University, Canada.

Luciann Crazyboy: Fourth-Year student, Bachelor of Child and Youth Care, MacEwan University, Alberta, Canada

Jereecah Dela Cruz: Fourth-Year student, Bachelor of Child and Youth Care, MacEwan University, Alberta, Canada.

Amanda Gladue: Fourth-Year student, Bachelor of Child and Youth Care, MacEwan University, Alberta, Canada.

Hailey Walper: Fourth-Year student, Bachelor of Child and Youth Care, MacEwan University, Alberta, Canada.

\begin{abstract}
A growing body of research shows that arts-based teaching and learning has the power to energize and promote student engagement by increasing opportunities for students to articulate their learning in many different ways. It is particularly effective for students who tend to struggle with the fast-paced and highly structured nature of mainstream education, which favours primarily cognitive and verbal forms of teaching and assessment. This study contributes to the scholarship of teaching and learning (SoTL) by reporting on the learning experiences of third-year child and youth care (CYC) students involved in an arts-based self-portrait assignment.
\end{abstract}

Key words: Arts-based, Child, Youth care, Education, Scholarship of teaching, Learning.

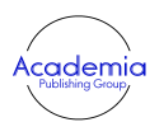

International Journal of Educational Studies Vol. 1, No. 2, pp. 92-101

Vol. 1 ,

DOI: $10.53935 / 2641-533 x . v 1 i 2.77$

Corresponding Author: Florin Dim

Funding: This study received no specific

financial support.

Article History:

Received: 12 April 2018

Revised: 16 September 2018

Accepted: 10 November 2018

Published: 21 December 2018

(C) 2018 by the authors: licensee Academic

Publishing Group

\section{Introduction}

I never knew where to start in writing a paper, so the creative arts assignment gave me the opportunity to demonstrate my learning in a way I could never achieve otherwise. - CYCW 302 student journal comments.

Gaining knowledge and expertise in arts-based therapeutic methods of intervention is a central pedagogical feature of relational-centred child and youth care (CYC) education. The quotation cited above is one of many drawn from a class of third-year CYC students who commented on an arts-based self-portrait assignment. The arts-based assignment was purposely planned to deepen students' creative capacities and confidence in using arts-based methods in their work with vulnerable children and youth. Arts-based education has been shown to have the power to energize and promote higher levels of student engagement and academic achievement by integrating the different ways in which students learn. Scholars such as Bellefeuille., McGrath, and Thompson (2012); Burnaford, Aprill, and Weiss (2001); Catterall (2000a); Catterall. (2000b); Deasy (2002); Deasy. (2003); Deasy.. and Stevenson (2005); Freeman, Seashore, and Werner (2003); Krause (2005); Livingston (2010); Horowitz (2005); Parsons 


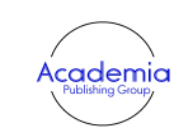

International Journal of Educational Studies Vol. 1, No. 2, pp. 92-101

2018

DOI: 10.53935/2641-533x.v1i2.77

"Corresponding Author: Florin Dima

Funding: This study received no specific

financial support.

Article History:

Received: 12 April 2018

Revised: 16 September 2018

Accepted: 10 November 2018

Published: 21 December 2018

(C) 2018 by the authors; licensee Academic

Publishing Group

$\mid 93$
(2005) and Robinson. (2006) all agree that arts-based teaching and learning encourages creativity, inspires imagination, promotes critical thinking, and has the potential to enhance student selfconfidence, self-esteem, and an overall sense of agency by increasing opportunities for self-expression and transcending cultural differences. Arts-based teaching and learning enables students to break out of established patterns of interpreting the world and better understand themselves and the uniqueness of others. This result is most profound for students who tend to struggle with the fast-paced and highly structured nature of mainstream education, which favours primarily cognitive and verbal forms of teaching and assessment (Smithrim \& Upitis, 2005).

\section{Encountering Relational-Centred Child and Youth Care Practice Through Arts-Based Teaching and Learning}

At the core of child and youth care (CYC) education is the belief that there is a powerful creative force within each of us and that the educational process should draw out and cultivate (Bellefeuille.., Ekdahl, Kent, \& Kluczny, 2014). As such, learning processes that incorporate the arts play important roles in teaching and learning. As poet and scholar John O'Donohue put it, -The imagination in its loyalty to possibility often takes the curved path rather than the linear wayll (Robinson, 2001). The strength of education that is achieved through the use arts is grounded in the belief that creativity is central to human learning because a creative learner is better able to engage in alternative ways of knowing that include -the spirit, mind, body, and emotional components of learningl (Merriam, Caffarella, \& Baumgartner, 2007). For example, Netzer and Mangano Rowe (2010) describe creative learning as learning that embraces -both rational and intuitive epistemologies\| (p. 141) that -[open] learners to multiple ways of knowing [by] developing [learners] experientially [, thereby] increasing the capacity for reflective awareness of self in relationships to a larger scope of being in the world\| (p. 125).

Creative learning through incorporation of the arts is more than simply conveying ontological -truthsl through the transmission, retention, and reproduction of knowledge via established scientific evidence. In contrast, it includes an aesthetic and ethical dimension that embodies Plato's characterization of the three realms of the good, the true, and the beautiful; these highlight the value ofprocess of discovery as much as the unearthing process itself (Bellefeuille.. et al., 2014). As Dirkx (2001) explains, the use of arts-based teaching and learning serves to revitalize students' level of somatic awareness, which results in richer and deeper learning experiences because they bring to consciousness the spiritual, emotional, and mythological aspects of the self. This notion is also supported by Lawrence (2005) who asserts that artistic ways of knowing create additional -intellectual spacel (p. 4) that allows us to draw on spiritual, somatic, and affective meaning. Additionally, arts-based education broadens one's cultural perspectives and helps uncover hidden knowledge that cannot be expressed easily in words (Brown, 2015). Recent developments in cognitive science and neuroscience help explain the power of arts-based teaching and learning. Neuroscientific research tells us that -the mind is embodiedl; in other words, the brain and body make up a single, fully integrated cognitive system. From a neuroscientific perspective, physical sensation and emotion are essential components of the mind-as integral to thought and learning as is logic (Damasio, 2003; Levitin, 2006; Parsons, 2005; Peterson, 1993; Ramachandran \& Hirstein, 1999).

\section{Building Evidence That Favours Arts-Based Education}

Despite growing evidence of the positive impacts generated by arts-based teaching and learning (Anne et al., 2011; Archibald, Caine, \& Scott, 2014; Florida, 2002; Mardirosian \& Lewis, 2009; Marshall, 2005) the arts are usually relegated to the sidelines during critical conversations in higher education. Consequently, the use of traditional transmission-based teaching techniques (i.e., lecturing) and conventional testing methods (e.g., multiple-choice exams, quizzes, academic papers) remains, for the most part, unexamined and unchanged. A major concern voiced by faculty in higher education is whether arts-based learning assessments can be reliably and objectively evaluated and graded. While traditional grading practices that rely on objective criteria are not well suited to arts-based assignments, subjective criteria such as evidence of critical thinking, originality of thought, depth of creative expression, and effort provide a transparent and sensible approach to assessing one's learning. 


\subsection{The Scholarship of Teaching and Learning}

In the pursuit of excellent scholarly teaching, this study contributes to the scholarship of teaching and learning (SoTL) by reporting on the learning experiences of third-year CYC students from an artsbased self-portrait assignment. Scholarship of teaching and learning is defined as the systematic study of teaching and learning, using established or validated criteria of scholarship, to understand how teaching. . .can maximize learning, and/or develop a more accurate understanding of learning resulting in products that are publicly shared for critique and use by an appropriate community (Potter \& Kustra, 2011).

Unique to this SoTL inquiry is the involvement of 6 fourth-year CYC undergraduate students. MacEwan University is an undergraduate institution that places great value on student engagement in all aspects of the teaching and learning process. Involving students as student research assistants not only enhances their research skills as they apply them in a practical setting, but it also builds their leadership skills and promotes collegiality. Felten (2013) identifies partnership with students as one of the five principles of good practice in the SoTL.

\subsection{CYC Practice Self-Portrait Arts-Based Assignment}

As part of a third-year advanced CYC practice methods course that has as its focus the integration of theory, self, and ethical practice, students are required to complete a -CYC practice self-portrait. The purpose of the assignment is to have students express and illustrate their understanding of - and personal insights into - the concepts discussed during the course, particularly in relation to their emerging professional identity as CYC practitioners. This assignment does not require any artistic training because the goal of arts-based learning is not to teach CYC students to be artists; rather, it aims to create immersive learning experiences that make use of artistic processes to help them gain new insights into and perspectives about their learning experiences.

Step One: Each student begins by selecting a bottle of any shape to design a symbolic or metaphoric representation of themselves (see Figure 1 and Figure 2). The self-portrait bottle provides a glimpse into the student's conscious and unconscious view of themself and their identity.

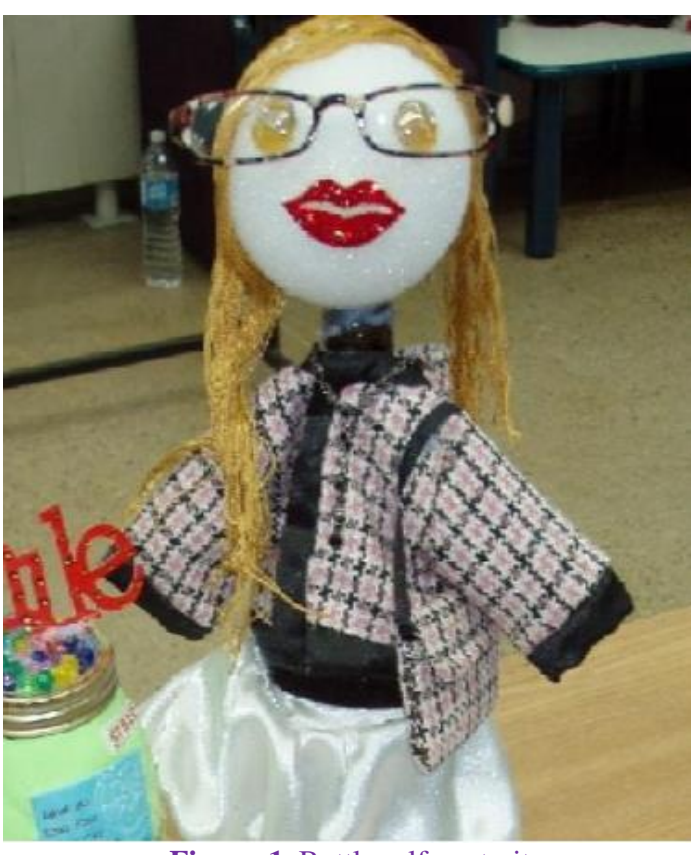

Figure-1. Bottle self-portrait.

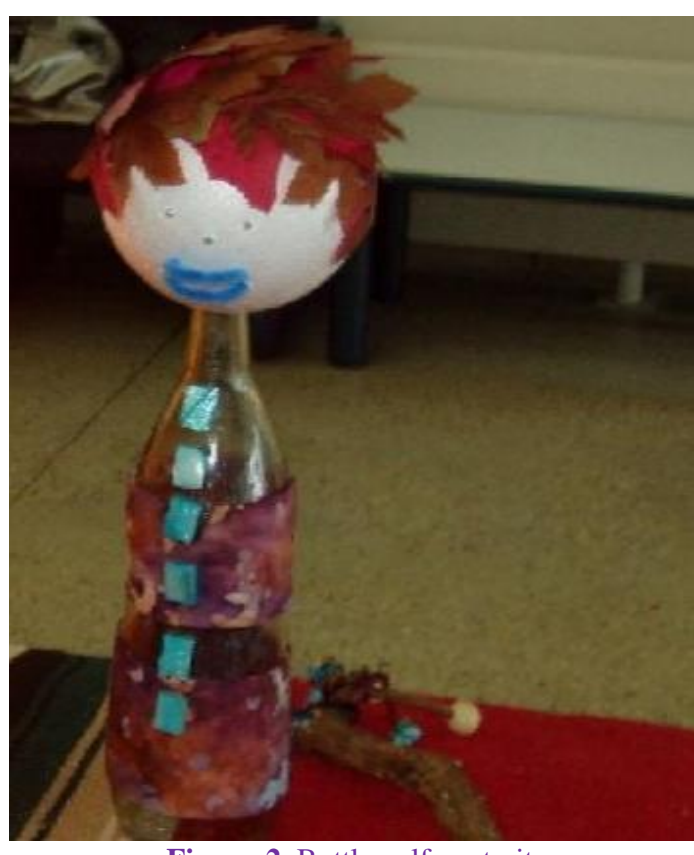

Figure-2. Bottle self-portrait.

Vol. 1, No. 2, pp. 92-101

2018

DOI: 10.53935/2641-533x.v1i2.77

Corresponding Author: Florin Dima

Funding: This study received no specific

financial support.

Article History

Received: 12 April 2018

Revised: 16 September 2018

Accepted: 10 November 2018

Published: 21 December 2018

(a) 2018 by the authors; licensee Academic

$\odot 2018$ by the authors
Publishing Group

| 94

Step Two: Following the design of their bottle self-portrait, each student is asked to construct creative background scenes to express their learning with and understanding of the course material using digital photography. The photos are electronically copied and pasted into a Word document and accompanied by a short explanation (see Figure 3 and Figure 4). 


\section{Thapter three: life Positic}

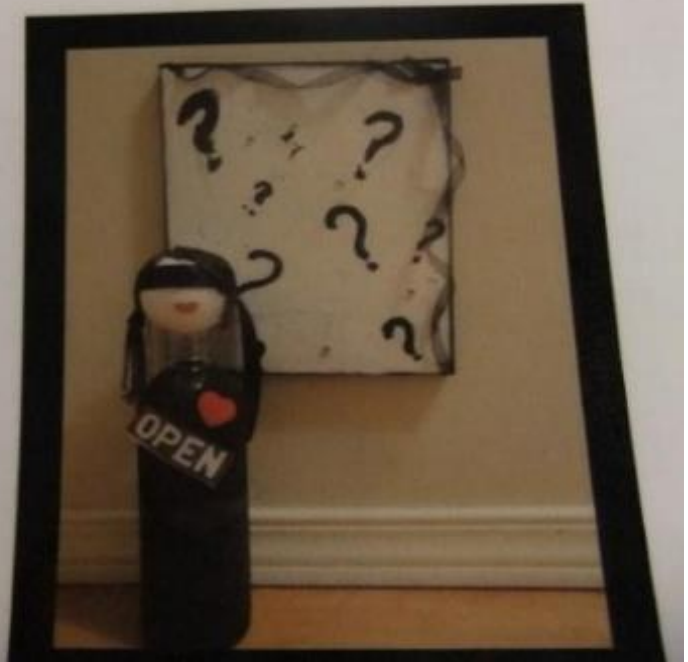

Figure-3. A background scene.

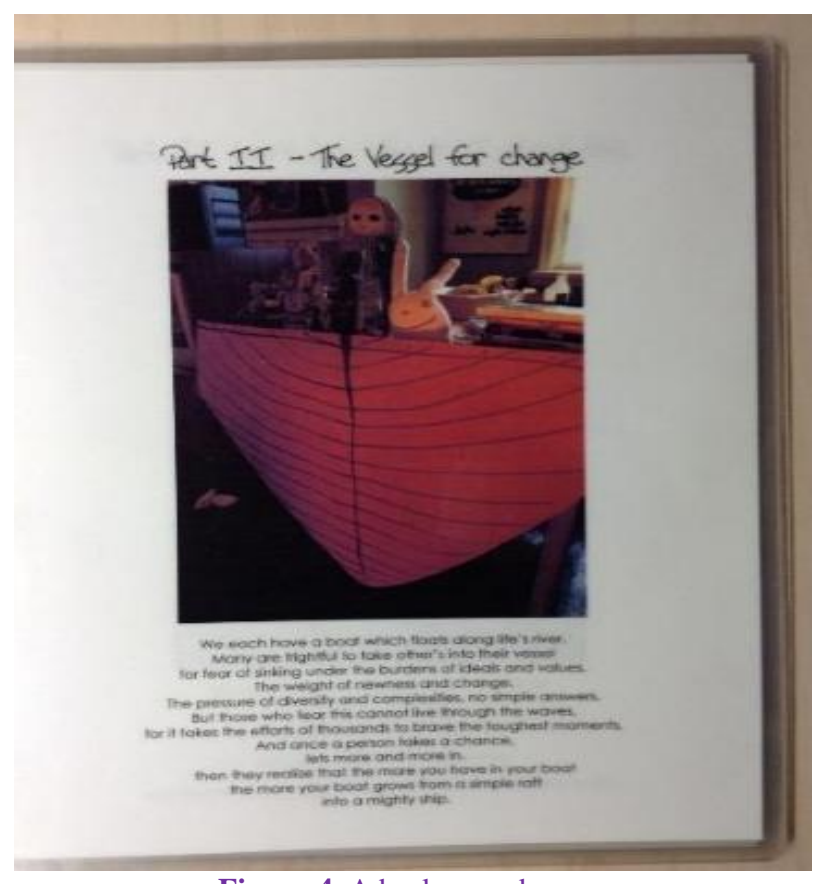

Figure-4. A background scene.

The course is structured around six distinct concept modules and students are required to design a minimum of one background scene per module. Together, these scenes create a colourful visual narrative, or storybook, in book form that expresses each student's CYC praxis self-portrait (see Figure 5 and Figure 6).

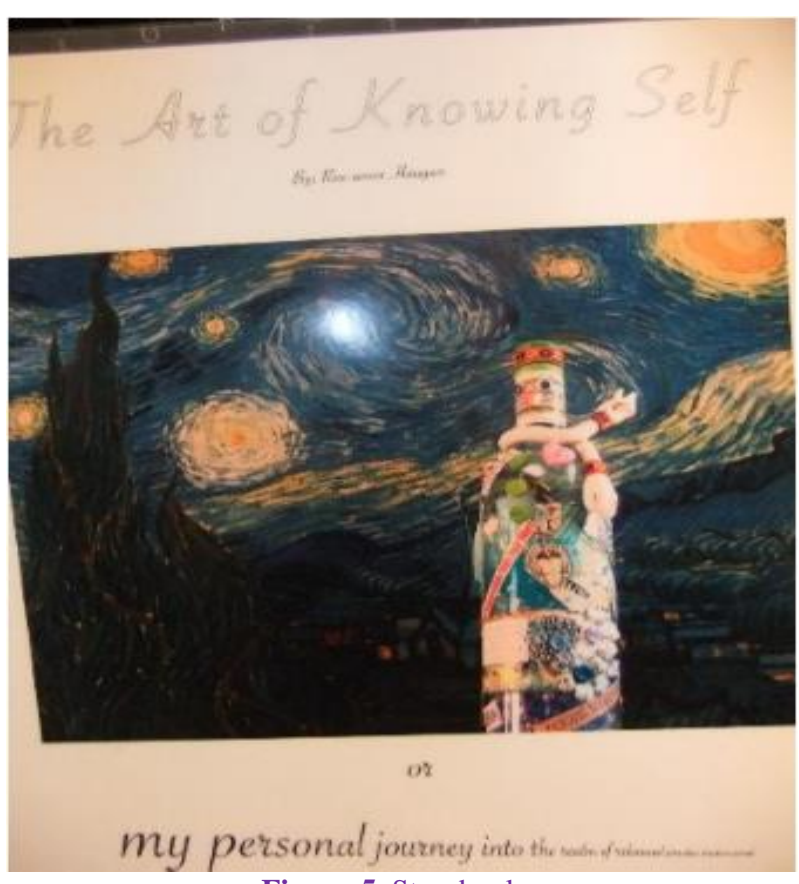

Figure-5. Storybook.

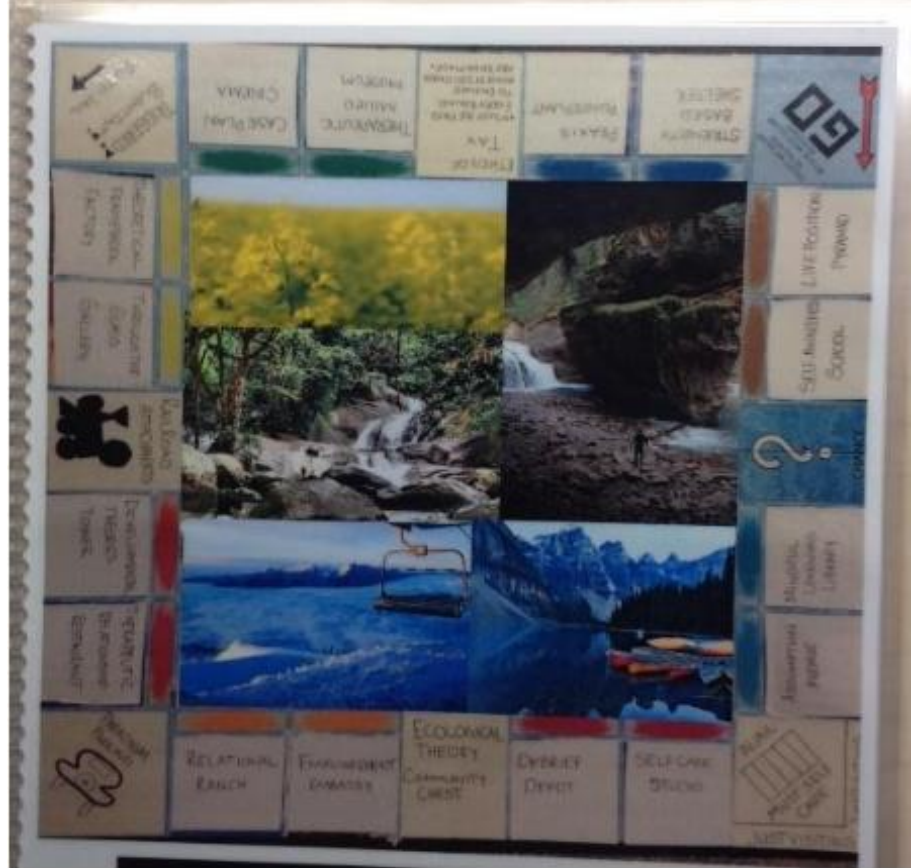

Figure-6. Storybook.

International Journal of Educational Studies Vol. 1, No. 2, pp. 92-101

2018

DOI: 10.53935/2641-533x.v1i2.77

Corresponding Author: Florin Dima

Funding: This study received no specific financial support.

Article History:

Received: 12 April 2018

Revised: 16 September 2018

Accepted: 10 November 2018

Published:21 December 2018

(C) 2018 by the authors: licensee Academic

Publishing Group

Using creative expression, students move beyond their everyday academic experience to reveal poetic and imaginative renderings inspired by the inner voices of their deepest selves. Participation in this creative process enables them to escape the habit of framing themselves and the world in accustomed ways. For many, the project is transformative in nature and enables them to overcome shyness, increase self-esteem and selfconfidence, and share their new awareness with their community. 
Step Three: At the end of the course, students' storybooks are displayed in a public showcase event attended by students, faculty, the general public, and public stakeholders. It's a -big deall for students to showcase their work (see Figure 7).

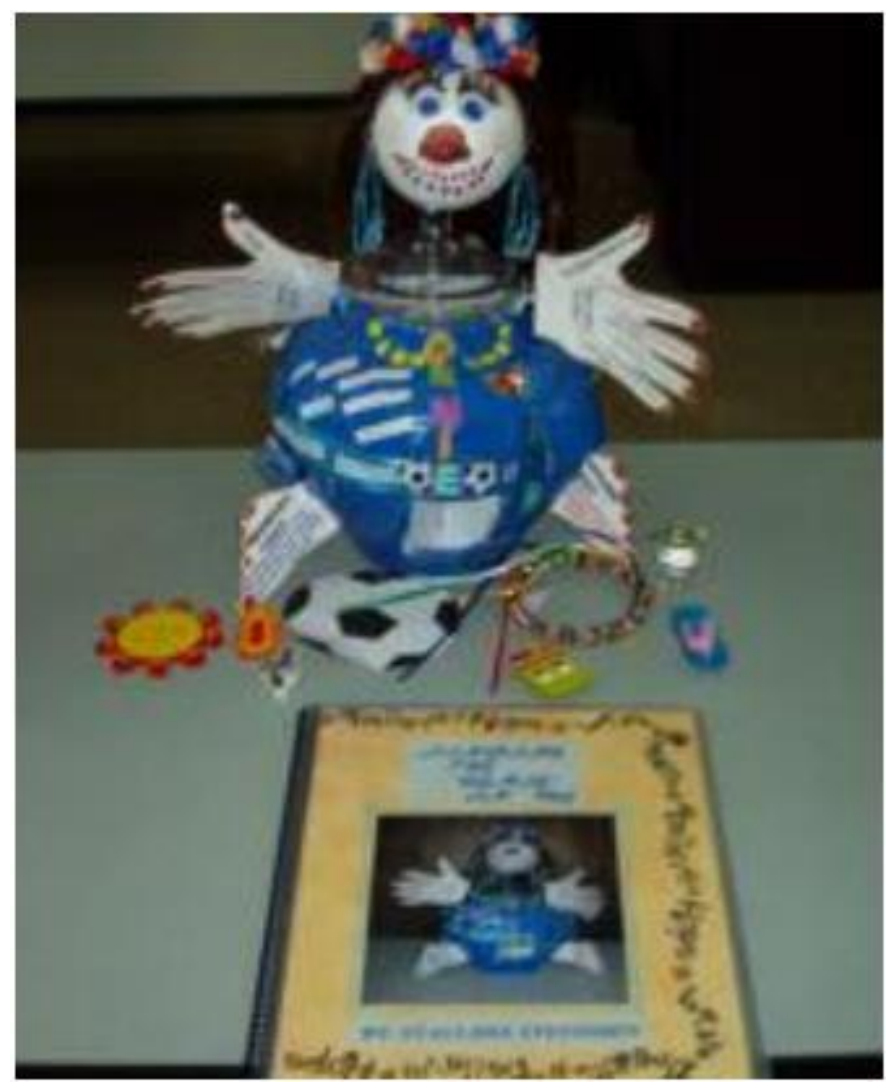

Figure-7. Storybook.

\section{Research Design}

As a professor of CYC at MacEwan University, I approach the teaching and learning of CYC practice as a deeply intrapersonal meaning-making process that occurs between self and others. As such, I have become deeply interested, during the past twelve years, in examining the academic and the personal impacts that arts-based learning assessments have on the learning experiences of CYC students. This study was designed with this interest in mind. The study was grounded in the relational-centred inquiry paradigm that honours the collaborative meaning-making process that is so central to relational CYC practice; its ultimate purpose is to improve teaching and learning in CYC education.

\subsection{Relational-Centred Inquiry}

Relational-centred inquiry is an approach - rather than a method of research - that rejects the methodological and individualistic distinction between self and other. As such, the goal of relationalcentred inquiry is for the

-researcher to involve him- or herself relationally with the other in dialogical methodologies that recognize the value of multiple realities and that ground knowledge development in experience and the ever-changing context of human service practicell (Bellefeuille \& Ricks, 2010). In practice, relationalcentred inquiry is a discovery-oriented process of meaning-making in which meaning (i.e., qualitative data) emerges out of co-created, embodied, and dialogical encounters shared by all participants. As Chen (2001) explains, meanings are the cognitive categories that make up one's view of reality and shape one's understanding of experience. Finally, relational-centred inquiry is a dynamic process in which both the researcher and participant share a journey of exploration by working together to plan, oversee, and draw conclusions from the data. As Gergen and Gergen (2003) point out, this is a sizeable conceptual shift that speaks to both a revision of the process and outcome of the research enterprise. Even 


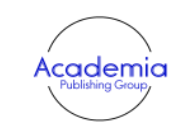

International Journal of Educational Studies Vol. 1, No. 2, pp. 92-101

2018

DOI: 10.53935/2641-533x.v1i2.77

Corresponding Author: Florin Dima

Funding: This study received no specific

financial support.

Article History:

Received: 12 April 2018

Revised: 16 September 2018

Accepted: 10 November 2018

Published. 21 December 2018

(C) 2018 by the authors: licensee Academic

Publishing Group

| 97 qualitative researchers, who reject universal claims of truths and accept that the world is socially constructed, maintain a posture of methodological and ideological individualism (p. 603).

\subsection{Ethical Considerations}

The study was approved by the Ethics Review Board (No. 16-17-063) of MacEwan University on April 4, 2017. All participants were given an information letter that described the purpose of the study and an informed consent form.

\subsection{Statement of the Research Question}

In this study, we wanted to gain insight into the learning experiences of third-year child and youth care students in completing an arts-based self-portrait assignment.

The specific research questions were the following:

1. Were you able to communicate your learning in the course more effectively through the expressive arts assignment than through more traditional types of learning assessments (e.g., quiz, essay questions, and theoretical paper)? If yes, please explain.

2. Did you find that creating the self-portrait bottle and storybook contributed to your thinking about and understanding of the key concepts you were working on? If yes, in what way?

3. When you look at your storybook now, what does it cause you to think about?

4. What challenges did you experience in completing the assignment?

5. What are your general opinions about your experiences in depicting thinking in a visual way?

\subsection{Sample Method}

A non-probability purposive sample of participants was recruited from CYC students at MacEwan University who had completed the arts-based CYC self-portrait assignment in the previous year. Students were approached in a classroom and provided with an information letter and consent form. Twenty-two students agreed to participate in the study. Purposive sampling is widely used in qualitative research for identifying and selecting individuals or groups of individuals that are available and willing to participate (Bernard, 2002), are knowledgeable about or experienced with a phenomenon of interest (Patton, 2002), and have the ability to communicate experiences and opinions in an articulate, expressive, and reflective manner (Miles \& Huberman, 1994).

\subsection{Data Collection Method}

The primary data collection strategy was semi-structured face-to-face interviews. Semi-structured face-to-face interviewing is appropriate where depth of meaning is sought and the principal aim of the research is to gain deep insight and understanding (Rubin \& Rubin, 2012). The interviews were recorded to allow for repeated review of the data, to check emerging themes, and improve the rigour of the research design.

\subsection{Data Analysis}

The interviews were audio recorded and listened to a number of times by the team of researchers to prepare for analysis. The inductive, or bottom-up, method of data coding described by Braun and Clarke (2006) was used to identify, analyze, and report patterns within data as themes. This required the researchers to familiarize themselves with the data, generate initial codes, search for themes, review themes, define and name themes, and produce the report.

\subsection{Methodological Rigour}

Investigator triangulation was employed to strengthen the methodological rigour of the research design and data analysis (Hays \& Singh, 2012). Each co-researcher undertook a separate analysis of the data, followed by analysis completed in pairs or small groups and, eventually, as one large group that sought to reach agreement on identifying evident codes and themes (Creswell, 2013; Hays \& Singh, 2012). Second, an audit trail was maintained to document our data analysis and research processes (Hays \& Singh, 2012; Schwandt, 2000). 


\subsection{Findings}

Thematic analysis of interviews resulted in the identification of six main themes. These included the following:

a) Greater Space for Self-Expression

b) A Journey of Self-Discovery

c) Empowering

d) A Deeper Learning Experience

e) Transformational

f) Feeling Exposed

\subsection{Greater Space for Self-Expression}

The majority of participants reported that the most meaningful aspect of the self-portrait assignment was that it allowed them to express their learning in innovative and creative ways. For example, one participant said, "I get so many words in my head and I don't know how to filter them to find what I'm trying to say. I can pick a picture and say, hey, this is what my brain is saying right now." Another stated, "the nice thing is this is a visual aspect that I can get a picture in my brain and be, like, that's what I want to display and I don't have to go through the struggle of trying to communicate it to people.\| Many of the participants commented that the arts-based self-portrait assignment brought about a cathartic release of emotions and feelings not normally associated with writing academic papers. As one participant noted, "I felt vulnerable completing this assignment because it was so personal. It brought out lots of emotions and feelings that really surprised me." Another participant said, "I experienced a lot of emotions as I created my bottle self-image and developed the background scenes and it felt more rewarding than writing assignments that is just using words."

\subsection{A Journey of Self-Discovery}

With respect to the theme of self-expression, participants described the process of creating their selfportrait as a journey of self-discovery. The most meaningful responses from participants focused on gaining insight about themselves. They gained new understandings about themselves and their identities as CYC practitioners. The themes and insights that appear in the following comments are consistent throughout the interviews: "Doing the assignment got me to think about who I am as a person and to recognize things about myself that I never really noticed before"; "Who am I? Looking for my identity, I have been searching since I was six years old and so this assignment has been a progression of what I have been doing"; "My story book would be different now: I've grown as a person, I've come to understand these theories better, I've come to understand myself as a person better"; "Truly it's been healing, there's healing for me here"; "It forces [me] to think about where $i$ was before the program and where i am now"; "I was able to learn more about myself in child and youth care. You can make it so much more personal. "Some participants also talked about their continuous journey: "The amount of growth that has happened, even since doing this assignment, is surprising"; "I still agree with everything I wrote, but I feel I just have more of an understanding and more enlightened to what I wrote. . when I wrote it" ; "I wouldn't really make this bottle again, because I feel I've progressed from there, it could be an extension to the bottle, where the bottle walks beside me, not needing that protection, I'll be outside the bottle."

\subsection{Empowering}

Another prevailing theme that emerged from interviews was the sense of empowerment, which was expressed in a variety of ways. For example, one participant stated that she finally felt that she had voice because she had been given the option to liberate her creativity to express her learning: "I felt like I finally have a voice." Many participants commented that the art assignment increased their confidence and self-esteem because it enabled them to show others how smart they are, intelligence that isn't necessarily revealed in the writing of papers or in taking quizzes: "I feel that this type of assignment was more reflective of my knowledge, [which] doesn't show up in paper writing"; "I think visually and feel things that I can't express through words, so it felt great to show off my abilities to my classmates and receive all their compliments." Other participants remarked that they felt greater ownership of their 
work: "For me, it's more my learning because I can't use other people's words so I am usingvisually-what I think about my learning to come across"; "Because I got to express myself in a way that is unique to me, I felt better, more content"; "This was the first assignment in my three years in the program that an instructor told me how impressive my assignment was. It made feel great.l

\subsection{A Deeper Learning Experience}

Benefitting from a deeper learning experience also emerged as a central theme. Several participants talked about how the arts focus pushed them to engage in the assignment, which resulted in a deeper learning experience: "The assignment caused me to have to better understand the concepts, because you had to engage with the material on a personal level"; "It forced me to go deeper, because I was showing myself to the public"; "I found that doing something creatively requires a deeper sense of the concept"; "Personal connection allowed me to apply the theories-and understand the theories-and get that deeper understanding"; "We can [dig] into that deeper learning if we incorporate more[of] these kind [s] of creative assignments"; "Things made more sense to me when I was able to make personal connection." Some participants commented on how the public nature of the showcase encouraged them to produce better work than they would have in the form of written papers that nobody, other than the instructor, would see: "Knowing that my classmates and the public will see my self-portrait assignment really pushed me to produce good work"; "The showcase made me realize that I was not faking and just saying what the instructor wanted to hear, so I took things much more serious[ly].”

\subsection{Transformational}

Another prominent theme that emerged was how participants talked about being engaged at a personal, emotional, and, even, spiritual level: "I found it very therapeutic; I was emotionally engaged and invested at a personal level. When I write papers, it is all about showing the instructor what they need to hear"; "It allowed me to express my faith, which does not happen in academic papers"; "I was really proud about my self-portrait, it is like a work of art that I want to keep." "I feel more confident now; before the assignment I felt fear and once I finished it I felt that I can be creative"; "I'm not [a] creative person; it pushes me out of my boundaries."

\subsection{Feeling Exposed}

Finally, for some participants, the arts-based self-portrait assignment generated feelings of insecurity, vulnerability, and exposure: "I hated this assignment because I am not creative"; "While I understood the rationale behind the assignment, I don't like to feel vulnerable, I don't like to be open, except for those who are close to me"; "I still feel insecure about sharing too much about myself in a public way"; "It can be scary to have to do things in a visual way, just because it's like there's a vulnerable aspect to yourself."

\section{Discussion}

This study provided this instructor with a valuable opportunity to gain insight into the potential of arts-based learning assessments to enhance student learning and to then share those insights with the broader teaching and learning community. The study explored the learning experience of students who participated in an arts-based CYC practice self-portrait assignment as part of students' third-year advanced CYC practice course. Overall, our analysis revealed six themes: (1) greater space for selfexpression, (2) a journey of self-discovery, (3) empowering, (4) a deeper learning experience, (5) transformational, and (6) feeling exposed. Each of the six interrelated themes occupy a place of growing importance in a higher education system that seeks to meet the learning needs of an increasingly diverse student population. One of the enduring challenges for higher education in the 21 st-century is to design learning environments that promote greater awareness among students of the breadth of voices and perspectives that exist, particularly with respect to global issues of social justice, diversity, and human rights, and, simultaneously, to accommodate a wide mixture of cultural learning styles and communication patterns (Bellefeuille. et al., 2012). As a teaching institution, it is important that MacEwan University embraces the science of teaching and learning as an essential element, not a choice. It is also important to recognize that the science of teaching and learning should be practised with 


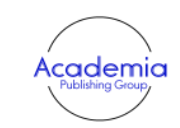

International Journal of Educational Studies Vol. 1, No. 2, pp. 92-101

2018

DOI: 10.53935/2641-533x.v1i2.77

-Corresponding Author: Florin Dima

Funding: This study received no specific

financial support.

Article History:

Received: 12 April 2018

Revised: 16 September 2018

Accepted: 10 November 2018

Published: 21 December 2018

(C) 2018 by the authors: licensee Academic

Publishing Group

| 100 students as partners (Felten, 2013). In essence, SoTL is concerned with researching how-and how well-students learn; equally important, however is the exploration of questions about the goals and purposes of higher education.

\section{References}

Anne, d. 1. C., Rose, C., Wildig, E., \& Willson, S. (2011). Arts-based learning in medical education:The students' perspective. Medical Education, 45(11), 1090-1100.

Archibald, M. M., Caine, V., \& Scott, S. D. (2014). The development of a classification schema for arts-based approaches to knowledge translation. Worldviews on Evidence-Based Nursing, 11(5), 316-324.

Bellefeuille, G., \& Ricks, F. (2010). Relational inquiry: A child and youth care approach to research. Children and Youth Services Review, 32(10), 1235-1241.

Bellefeuille., G., McGrath, J., \& Thompson, B. (2012). A creative arts approach to teaching and learning: A vehicle to promote critical child and youth care praxis. In G. Bellefeuille, D. Jamieson, and F. Ricks (Eds.), Standing on the precipice: Inquiry into the creative potential of child and youth care practice 2nd (pp. 303-335). Edmonton, AB: MacEwan Press.

Bellefeuille.., G., Ekdahl, C., Kent, L., \& Kluczny, M. (2014). A course-based creative inquiry approach to teaching introductory research methods in child and youth care undergraduate education. International Journal of Teaching and Education, 2(2), $1-9$.

Bernard, H. R. (2002). Research methods in anthropology: Qualitative and quantitative approaches (3rd ed.). Walnut Creek, CA: Alta Mira Press.

Braun, V., \& Clarke, V. (2006). Using thematic analysis in psychology. Qualitative Research in Psychology, 3(2), 77-101. Available at: https://doi.org/10.1191/1478088706qp063oa.

Brown, S. (2015). Creativity, social justice and human rights within adult education. International Journal of Adult Vocational Education and Technology (IJAVET), 6(2), 1-12.

Burnaford, G., Aprill, A., \& Weiss, C. (2001). Renaissance in the classroom: Arts integration and meaningful learning. Erlbaum: Mahwah, NJ.

Catterall, J. S. (2000a). The arts and the transfer of learning. In R. J. Deasy (Ed.), Critical links: Learning in the arts and student academic and social development (pp. 151-157). Washington, DC: Arts Education Partnership: .

Catterall., J. S. (2000b). Research on drama and theater in education. In R. J. Deasy (Ed.), Critical links: Learning in the arts and student academic and social development (pp. 58- 62). Washington, DC: Arts Education Partnership.

Chen, C. P. (2001). On exploring meanings: Combining humanistic and career psychology theories in counselling. Counselling Psychology Quarterly, 14(4), 317-330. Available at: https://doi.org/10.1080/09515070110091308.

Creswell, J. W. (2013). Qualitative inquiry and research design: Choosing among five approaches (3rd ed.). Thousand Oaks, CA: Sage.

Damasio, A. (2003). Looking for spinoza: Joy, sorrow, and the feeling brain. New York: Harcourt Brace.

Deasy, R. J. (2002). Critical links: Learning in the arts and student achievement and social development. Washington, DC: Arts Education Partnership.

Deasy., R. J. (2003). Creating quality integrated and interdisciplinary arts programs: A report of the arts education national forum. Washington, DC: Arts Education Partnership.

Deasy.., R. J., \& Stevenson, L. (2005). Third space: When learning matters. Washington, DC: Arts Education Partnership.

Dirkx, J. (2001). The power of feelings: Emotion, imagination and the construction of meaning in adult learning. In S. Merriam (Ed.), New update on adult learning: New directions for adult and continuing education (pp. 63-72). San Francisco, CA: JosseyBass.

Felten, P. (2013). Principles of good practice. Teaching and Learning Inquiry, 1(1), 121-125. Available at: http://dx.doi.org/10.2979/teachlearninqu.1.1.121.

Florida, R. (2002). The rise of the creative class. New York: Basic Books.

Freeman, C., Seashore, K. R., \& Werner, L. (2003). Models for implementing arts for academic achievement: Challenging contemporary classroom practice. Center for applied research and educational improvement, college of education and human development: University of Minnesota.

Gergen, M. M., \& Gergen, K. J. (2003). Social construction: A reader. Thousand Oaks, CA: Sage.

Hays, D. G., \& Singh, A. A. (2012). Qualitative inquiry in clinical and educational settings. New York: Guilford Press.

Horowitz, R. (2005). Connections: The arts and cognitive, social, and personal development. In b. Rich (ed.), partnering arts education: A working model from arts connection (pp. 32-48). New York: Dana Press.

Krause, K. (2005). Engaged, inert, or otherwise occupied? Deconstructing the 21st century undergraduate student. Keynote paper presented at sharing scholarship in learning and teaching: Engaging students (pp. 21-22). Townsville and Cairns, Queensland: James Cook University.

Lawrence, R. L. (2005). Artistic ways of knowing: Expanded opportunities for teaching and learning. San Francisco, CA: Jossey-Bass. Levitin, D. J. (2006). This is your brain on music: The science of a human obsession. New York: Dutton/Penguin.

Livingston, L. (2010). Teaching creativity in higher education. Arts Education Policy Review, 111(2), 59-62.

Mardirosian, G. H., \& Lewis, Y. P. (2009). Arts-based teaching: A pedagogy of imagination and a conduit to a socially just education. Current Issues in Education, 12(10), 1-21.

Marshall, J. (2005). Connecting art, learning, and creativity: A case for curriculum integration. Studies in art Education, 46(3), 227241.

Merriam, S. B., Caffarella, R. S., \& Baumgartner, L. M. (2007). Learning in adulthood: A comprehensive guide. San Francisco, CA: John Wiley \& Sons. 
Miles, M. B., \& Huberman, A. M. (1994). Qualitative data analysis: An expanded sourcebook (2nd ed.). Thousand Oaks, CA: Sage.

Netzer, D., \& Mangano Rowe, N. (2010). Inquiry into creative and innovative processes: An experiential, whole-person approach to teaching creativity. Journal of Transformative Education, 8(2), 124-145.

Parsons, M. (2005). The role of the visual arts in the growth of mind. review: The arts and the creation of mind by ew eisner; art and cognition: Integrating the visual arts in the curriculum by ad efland. Studies in art Education, 46(4), 369-377.

Patton, M. Q. (2002). Qualitative research and evaluation methods (3rd ed.). Thousand Oaks, CA: Sage.

Peterson, M. A. (1993). The ambiguity of mental images: Insights regarding the structure of shape memory and its function in creativity. In B. Roskos-Ewoldsen, M. J. Itons-Peterson, and R. Anderson (Eds.), Imagery, creativity, and discovery: A cognitive perspective (pp. 151-185). Amsterdam, Netherlands: North-Holland.

Potter, M. K., \& Kustra, E. D. (2011). The relationship between scholarly teaching and SoTL: Models, distinctions, and clarifications International Journal for the Scholarship of Teaching and Learning, 5(1), 23.

Ramachandran, V. S., \& Hirstein, W. (1999). The science of art: A neurological theory of aesthetic experience. Journal of consciousness Studies, 6(6-7), 15-51.

Robinson, K. (2001). Out of our minds: Learning to be creative. Oxford, UK: Capstone.

Robinson., K. (2006). Ken Robinson says schools kill creativity. Video on TED.com. TED Ideas worth spreading.Retrieved from: http://www.ted.com/index.php/talks/ken_robinson_says_schools_kill_creativity.html.

Rubin, H. J., \& Rubin, I. S. (2012). Qualitative interviewing: The art of hearing data (3rd ed.). Thousand Oaks, CA: Sage.

Schwandt, T. A. (2000). Three epistemological stances for qualitative inquiry: Interpretivism, hermeneutics, and social constructionism. In N.K. Denzin and Y.S. Lincoln (Eds.), Handbook of qualitative research (2nd ed.). Thousand Oaks, CA: Sage.

Smithrim, K., \& Upitis, R. (2005). Learning through the arts: Lessons of engagement. Canadian Journal of Education, 28(1\&2), 109127. 